April - 2004

\title{
Interim Report: A case study of Internet-based distance education program development in Vietnam
}

\author{
Ramona R. Materi \\ Ingenia Consulting \\ Patrick J. Fahy \\ Athabasca University - Canada’s Open University
}

\section{Introduction}

This is a report of the role of Distance education (DE) in enhancing education and training in developing countries. As countries compete in an ever more challenging international marketplace, they recognize the need to continually train and upgrade their citizenry. As national leaders struggle to cope with increasing populations and decreasing budgets, DE can be an additional and often essential tool in accomplishing this goal.

This paper is a case study of the efforts of one college in Vietnam, Fisheries College Number 4, to develop a plan to introduce a small distance education offering to its regular courses. Its purpose was to better serve farmers in remote regions. The first author, Ramona Materi, through her company, Ingenia Consulting, carried out the work on behalf of the International Development Research Centre (IDRC), a public corporation created by the Parliament of Canada to help researchers and communities in the developing world to find solutions to their social, economic, and environmental problems. Materi's assignment was to work with College officials to develop the DE plan and funding proposal.

The paper begins with a brief description of the role of information and communications technology (ICT) in education and development, particularly in South East Asia. It then provides an overview of Vietnam and its current activities in DE. The next section offers a detailed examination of the challenges the College faced in developing a plan for DE on the Internet. The paper concludes with Materi's personal observations and commentary on lessons learned.

\section{ICT'S Role in Education and Development}

The debate on the role of education and development is complex as the appropriate role of DE, and more specifically the use of DE technologies, in advancing economic and social well being. Commenting on distance education, Chung (1990) notes:

Given the limited human and financial resources available to third world countries, distance education becomes an invaluable tool for development. Through distance education, one teacher can reach an audience of millions rather than only a handful. The cost of distance education can 
be a fraction of that of traditional formal education, thus enabling limited resources to reach a larger population (p. 64).

Casas-Armengol and Stojanovich (1990) argue that the "rational and well-planned use of new and advanced technologies" in distance education can enable developing countries to break out of offering degrees for social prestige and instead allow "true knowledge development” (p. 133).

Other writers, however, wonder if advanced multimedia technologies are practical for poor countries. As Penalever (1990) comments:

The application of modern technologies will entail an increase in the costs to be borne by the students, which, in turn, will affect their access. It is possible that third world countries will not be able to make use of the "technologically advanced" new modalities of distance teaching, which are being developed at present in industrialized countries (p. 28).

These concerns, though, have been no barrier to the use of interactive DE technology in Asia, as academic conferences throughout the years demonstrate. In 1990, the Universitas Terbuka in Indonesia hosted the "Interactive Communication in Distance Education" conference, at which scholars from DE institutions throughout the region discussed ways to increase two-way interaction between instructors and students. In 2001, another Indonesian conference with the same theme appeared, "Facing Global Competition: Open learning and Information technology: Problems and Promises" (2002), where scholars looked at quality issues in online learning and teaching, and other related topics.

Nonetheless, access to Internet technology varies widely in the region. The Asian Development Bank has prepared a series of reports looking at infrastructure problems and related matters. Countries, like Singapore and Malaysia, have solid structures in place, and others like Thailand and the Philippines are moving towards better connectivity, while others like Vietnam, Laos, and Cambodia require major investments to upgrade their technological networks. The majority of these countries, however, recognize the importance of the Internet and the urgency of investing in essential telecommunications infrastructure (Murray, 2003). Thus, distance educators working in the region must plan to deal with a wide range of capabilities when designing programs.

\section{Background of Vietnam}

Vietnam is considered one of the poorest and most underdeveloped countries in the world. As the CIA Fact Book (2002) notes: "Vietnam is a poor, densely populated country that has had to recover from the ravages of war, the loss of financial support from the old Soviet Bloc, and the rigidities of a centrally planned economy." The country was at war from 1945 to 1975, after which it faced an economic embargo until 1990. From 1993-1997, growth averaged 9 percent per year, but it has slowed in recent years because of the recession in the global economy and in South East (SE) Asia. With a population of 78 million, almost 80 percent of the workforce is involved in agriculture and lives in rural areas. In 2000, Gross Domestic Product (GDP) per capita was estimated at US \$300 per year.

With respect to education, Vietnam faces several urgent needs. With more than 75 percent of its population under the age of 30, it has numerous new students entering the primary and secondary schooling systems. It also has massive numbers of people to train in new technologies and practical skills to achieve economic development. Less than 25 percent of the total workforce is skilled labour. According to Thai Thanh Son (2001), an analyst working for the United Nations Development Program in Vietnam: 
Retraining, upgrading and standardizing working staff in all sectors of the national economy is [urgently required]. Approximately 80 percent of the country's workforce was originally trained along different lines. Consequently, they are not adequately prepared for today's economy and they need additional training.

As an example, the Vietnamese government has created Export Processing Zones, to encourage socio-economic development in rural areas. In one zone in Quang Ngai province, an oil refinery complex will need 4,000 engineers and 12,000 skilled workers by 2005. With the current state of education and training, however, the complex will do well to have 5 to 10 percent of that required workforce. Similarly, for lack of qualified Vietnamese personnel, British Petroleum, a multinational working with the Vietnamese government to develop offshore oil, must import engineers and oil field specialists from Thailand. The shortage of skilled workers is endemic across industries outside of the agricultural sector (McTavish, 2003).

\section{Distance Education in Vietnam}

Vietnam has been involved in distance education since the 1950s. Faced with swelling numbers of students and needs, the government is beginning to invest more in the sector. In particular, it believes that DE can be effective in promoting human resources training (Son, 2001).

In the mid-1950s, many colleges and universities established units and departments for correspondence training. In the 1980s and 1990s, the government established more formal DE institutions, including the Vietnam Institute of Open Learning (1988), and the Open Learning Institutes of Hanoi and Ho Chi Minh (1990). In 1993, the government established the Hanoi State Open University and the Semi-Public Open University in Ho Chi Minh City. These institutions manage and organize open learning and distance education throughout Vietnam.

In 1998-1999, approximately 800,000 learners participated in some sort of open learning or distance education offering. These included 40,000 undergraduate in-service learners, 10,000 students of in-service secondary vocational education, 100,000 continuing education students, 400,000 foreign language students, and 250,000 people upgrading literacy. Thousands of others participated in seminars and workshops (Global Distance Learning Network, 2001).

Much of the DE offered in Vietnam is print-based. Ha Noi Open University (HOU), for example, has regional learning centres throughout the country. Students receive their materials by mail or pick them up from the centres. HOU also produces audio and video materials for select courses and has videoconference facilities, funded by the World Bank. It has a simple website, and sends

emails to the regional centres for basic administrative matters. HOU's offerings mirror those of most other Vietnamese institutions.

The use of Internet for DE is relatively rare due to such constraints as:

- Lack of Equipment/ Infrastructure: In 2001, fewer than 100,000 people in Vietnam had private access to the Internet. For instance, only 10 percent of the students in the Faculty of Information Technology at the Hanoi State Open University had their own computer. Most use public-access computers in cyber cafes, which are ubiquitous; even small towns are likely to have access. Still, this access also has problems. Vietnam's Internet backbone has only one major line between Ha Noi and Ho Chi Minh, and military traffic has priority. For the average user access can be grindingly slow and unreliable. 
- Expense: In a country where average annual income is about US \$300, in 2003 a new desktop computer started at US \$800. Costs for Internet and telephone services are equally prohibitive when compared to average income. Relative to an on-campus student, a learner using the Internet for an hour a day would end up paying four to five times as much in fees.

- Language/ Culture: Language barriers are also present. Users require a certain proficiency in English to log onto websites, participate in chat rooms, and gain access to the information resources of the Net. The Vietnamese government also restricts access to certain sites.

- Instructional Design Capacity: There are few capable DE instructional designers in Vietnam, and fewer still experienced designers of materials for the Internet. Through its Mekong Delta Facility, the World Bank is engaged in a year long project to enhance the print-based design skills of a select group of instructional designers. In 2004, this group will turn to CD-ROM technology. State-owned companies have these capabilities as well, but even they acknowledge the need for further skills training and upgrading (Nelson, 2003; Nguyen, 2003).

Despite these constraints, Internet usage in Vietnam is growing. Infrastructure problems are being remedied with Asian Development Bank funding, Vietnam plans to install fibre optic networks in the Northern provinces by 2005. The "pipeline" between Ho Chi Minh and Saigon should be double-tracked by the end of 2003 (Chang, 2003). As for language, many young people study English, and it is common in large city cyber cafes to see them chatting for hours online, alternating between Vietnamese, French, and English language forums.

As these problems are resolved, the likelihood of Internet usage for DE is enhanced. Already, Vietnam and Japan have signed an agreement on e-Learning, whereby the Hanoi Institute of Technology, Vietnam's 's premier information technology (IT) facility, is working with Japan's Kyoto University to explore the use of e-learning for IT courses. Such initiatives are likely to continue to expand. The rest of this paper will describe how one college is moving forward to use the Internet as a DE teaching tool (Nguyen, 2003).

\section{The Challenges for Fisheries College Number 4 of Introducing the Internet}

\section{The Training Challenge}

Located outside of Ha Noi, Fisheries College Number 4 is responsible for providing college level and continuing education courses to students and workers in the northern provinces of Vietnam. Its courses range from business and accounting to aquaculture, information technology, and food processing technology.

The fisheries sector is important to Vietnam, employing millions of people, contributing four to five percent of GDP annually, and nine to 10 percent of Vietnam's total exports. The government would like to increase the number of fisheries technicians by 20 percent between 2000 and 2010 . The goal is to create jobs for two million people in aquaculture; at present, only 30 percent have been trained. In Vietnam, aquaculture is carried out at home in rural areas, with 45 percent of the workforce comprising women. Because the government sees aquaculture playing a major role in improving the role of women in rural and mountainous areas, the priority need is for worker training in rural areas (Wyne, 2002). 
In support of this goal, the College has developed a one-week, in-person short course in aquaculture targeting farmers. Instructors from Ha Noi help locally based staff deliver the course, traveling to learning centres in rural areas. They are away from the college for up to one month at a time. The College has a large area where it houses various species in aquaculture ponds, which are used to train farmers and regular students. As part of the government's rural development efforts, courses for farmers are offered free of charge. Class sizes range from 45-100 people, with the College offering the sessions two to three times per year.

This current training model places pressure on college staff, learners, and facilities; increasing the number of classes, learners, and teaching locations would only exacerbate the strain. Instructors must travel frequently in rural areas along roads crowded with carts, bicycles, and slow moving trucks, making for long, tiring, and dangerous journeys. Students also face difficult travel conditions and many must also be away from home and family responsibilities for extended periods.

To alleviate these problems, the College approached the Canadian International Development Research Centre (IDRC), seeking funding for the use of ICT to meet the needs of farmers. The first author was the consultant who carried out the development of a DE plan and funding proposal.

A basic needs assessment revealed the following issues related to the implementation of ICT in distance education:

- Teaching and Learning: The College had worked previously with Canadian donor agencies, including the Marine Institute, and the College of the North Atlantic in Newfoundland. As a result, it had a selection of audiovisual equipment and had produced 12 courses using systematic instructional design techniques. Once funding ceased, however, so did the use of these skills. Since 1997, when the design project ended, the College has designed no new courses using these techniques, nor has it revised any existing ones. Further, College instructors had minimal to non-existent experience with DE courses. None had ever developed materials for such courses, nor instructed in them. Some had basic computer and Internet skills, but only two IT instructors were acquainted with the technology.

Student skills were equally limited. Farmers ranged in age from 25 to 65, and their computer skills were almost non-existent. All, however, had excellent literacy skills; the United Nations Development Program estimates literacy rates in Vietnam at more than 90 percent.

- Technical Considerations: In Ha Noi, the College has a computer lab with relatively new computers. Only two computers, however, were connected to the Internet, and these were located in the director's and vice-director's offices. Connection speed was 11.5 Kbps, excruciatingly slow and unsuitable for DE activities.

The College has spent more than \$US 750,000 developing an extension training centre in Quang Ninh, a province about three hours from Ha Noi. In September of 2002, navigating the road required a four wheel drive vehicle after any rainfall. One building had a large room, which with air conditioning and rewiring upgrades, could accommodate a computer lab. Tests for connectivity at the College showed that speeds of 28.8Kbps were possible. The extension centre, however, had no computers. 
- Change Management: For more than 40 years, the College had specialized in face-toface training. No one had experience in budgeting for, planning, or administering DE programs, or seeing to student needs and related matters. If handled badly, introducing $\mathrm{DE}$ as well as the Internet could thus pose imposing organizational challenges.

- Cost and Budgets: Funds for education in Vietnam are limited. As such, the College would have to rely on outside, foreign donors to provide the financing necessary to train staff and purchase necessary equipment.

\section{The Proposed Solution}

The College decided to offer learners the option of taking the aquaculture course through DE. It sought to take advantage of current delivery trends in the developed world, which are to use the Internet and other ICT technologies to increase course quality and opportunities for interactivity. The College proposed a blended approach, whereby students would receive theoretical and supplemental information through DE, and the practical portion via face-to-face instruction in the field.

In pursuing this model, the College would be a leader and a pioneer; as mentioned previously, few post-secondary institutions in Vietnam are using the Internet for training purposes, and even then the scope of use is more limited than that which the College is proposing.

\section{Specific Objectives}

The overall objective of the project was to pilot the use of ICT tools in support of DE in rural areas of Vietnam. In addition, the project was designed to demonstrate the effectiveness of blended training as a development educational tool with rural adult learners. More specific objectives include:

1. Investigate whether the College can maintain quality learning by:

a. Developing, delivering and maintaining a combination of classroom and Internetbased learning

b. Exploring innovative strategies for using simple websites as a means to distribute scientific and technical information to rural audiences

2. Evaluate the effectiveness of various ICT tools as distance education tools for the Fisheries College by using servers and other tools that Vietnamese Internet service providers have developed specifically for the Vietnamese language, and for the slow connectivity typical of rural areas

3. Assess the effectiveness of the pilot project by collecting data on:

a. Instructor and learner satisfaction with the educational process and outcomes

b. Reliability of the ICT tools employed

c. Feasibility of expanding the model to other courses and potentially other colleges in Vietnam

The College would establish a DE teaching centre on its main campus, with computers connected to the Internet. College instructors would use this teaching centre to create DE materials for Internet delivery, respond to student inquiries, and conduct research to help them develop courses with the latest scientific and technical information. 
The College would set up a second DE centre at its Quang Ninh extension centre. For the pilot course, farmers would still attend classroom and field sessions. In addition, they would receive training in computer and Internet skills, and have access to supplementary materials that College instructors develop. This material would include information on aquaculture theory and techniques, as well as relevant information on Ministry of Fisheries programs.

The technologies the College plans to use include:

- Microsoft FrontPage for development of Web-based course information

- Adobe Acrobat for the development of PDF files for the course website

- Computers networked in a local area network, connected by a server to the Internet

\section{Proposed Process}

Described is an overview of the methodology for the project, developed by the College in conjunction with international advisors. Divided into three phases, the aim of the project is to address some potential pitfalls uncovered in the needs assessment.

\section{Phase 1: Preparation}

In this phase, lasting approximately eight months, the College will work with stakeholders, a local Internet Service Provider (ISP) NetNam, and foreign consultants to develop staff capacity in Internet technology and DE training. It will also set up the distance learning centres. Major activities will include:

- Stakeholder Meeting: To start the project, the College will hold a three day meeting with staff, farmers, Ministry of Fisheries officials, and other interested parties, to inform them of the project and to discuss and conduct detailed planning for project activities.

- Establishment of Internet-Connected DE Centres: The College will contract with NetNam to develop two Internet-connected DE centres, one in the College and one its Quang Ninh extension center.

- Staff Workshops/ Formal Training in ICT Technologies: NetNam will provide workshops on network administration, basic computer and Internet skills, and webpage construction skills to pertinent staff. Specifically, the College will contract with NetNam for:

1. A survey of the level of connectivity at each proposed site. NetNam will then provide advice on how to make arrangements to increase these speeds

2. Advice on equipment, help with arrangements to acquire it, and quality testing once purchased

3. Installation of equipment in the two DE centers

4. One two-day workshop for 20 teachers on basic computer and Internet skills

5. One two-day workshop for the same 20 teachers on basic Web-design skills

6. Ongoing telephone (and, as necessary, on site) technical support for the DE centres

- Staff Training in DE: An international consultant will provide a one-week workshop (delivered in a two-week timeframe to allow for translation time) to 20 College instructors on the development of teaching materials for the Internet. Using the existing 
course for farmers, the consultant will work with instructors to show them how to use materials from the Internet and paper sources, and use them to create an attractive and useful educational website that supports classroom teaching.

- Additional Training in Canada: Two College aquaculture instructors will receive advanced training in the latest ICT distance education techniques through on-site training in Canada. Training will take place at one or two selected institutions, over a period of two weeks.

- Development of Online Course Materials: College instructors will prepare appropriate Web-based materials for the course.

\section{Phase II - Implementation}

The process in the second phase, implementation, lasting approximately 14 months, will consist of:

- Course Delivery: The College will use Internet technology to deliver the course two to three times in each center, to classes of between 45 and 100 students. Farmers will have access to the labs over the entire week and will be able to review Web-based materials in shifts, as computers are available. For example, one group may attend a field session, while another group works in the computer lab.

- Course Revisions and Adjustment: After an initial round of courses, the College will revise course materials, with the help of an international advisor, who will visit for one week.

\section{Project Schedule}

Table 1 shows the two-year project schedule: 
Table 1. Implementation Schedule

\begin{tabular}{|l|c|}
\hline Major Milestones & Timing \\
\hline Project start & Month 1 \\
\hline Stakeholder meeting & Month 1 \\
\hline $\begin{array}{l}\text { NetNam survey and preparation of } \\
\text { computer network, DE centre staff } \\
\text { training }\end{array}$ & Month 1 to Month 8 \\
\hline $\begin{array}{l}\text { Web development, network } \\
\text { administration and other technical } \\
\text { skills workshops for College staff }\end{array}$ & Month 2 to Month 4 \\
\hline $\begin{array}{l}\text { In-country training workshop of } \\
\text { College staff in DE techniques }\end{array}$ & Month 3 or 4 \\
\hline $\begin{array}{l}\text { DE study tour to Canada for 6 } \\
\text { people }\end{array}$ & Month 5 \\
\hline DE materials complete & Month 8 \\
\hline First round of course delivery & Month 9 to Month 12 \\
\hline $\begin{array}{l}\text { Course revisions with assistance } \\
\text { from International consultant }\end{array}$ & Month 13 \\
\hline Second round of course delivery & Month15 to Month 17 \\
\hline Third round of course delivery & Month 21to Month 23 \\
\hline Stakeholder meeting & Month 24 \\
\hline Submission of final report to IDRC & \\
\hline
\end{tabular}

\section{Monitoring and Evaluation}

The College will undertake several activities to evaluate project quality. The areas it will assess include:

- Learner and Instructor Satisfaction: Internet supported courses will be new to students and instructors. The College will use questionnaires, focus groups, and interviews to gather data on their reactions, experiences and suggestions for improvement.

- Equipment/ Internet Reliability: Administrators of the DE centres will log equipment breakdowns, Internet service interruptions, electricity failures, and other technical difficulties that may affect the College's ability to deliver the course.

- Feasibility of Project Expansion: At the final stakeholder meeting, participants will discuss and evaluate the possibility of the College expanding online courses to its 
students, as well as the potential of offering courses to other students enrolled in other fisheries colleges in Vietnam and elsewhere.

Outputs from the project will include:

- Establishment of a DE centre at the Fisheries College Number 4 main campus, and at Quang Ninh.

- Development of Vietnamese language Web-based course materials for aquaculture training.

- Capacity building for College staff in network administration, Internet and Web design skills, and ICT-supported distance education.

- Capacity building for students in computer and Internet skills, and the latest techniques in aquaculture.

- $\quad$ Report assessing the viability of ICT supported DE in Vietnam's rural areas.

\section{Project Beneficiaries}

- Farmers: The computer and Internet skills farmers gain may help them in other ways in the future. As e-commerce in Vietnam develops, they will have access to market information to help them receive a better price for their product. Since aquaculture is more profitable than traditional rice farming, farmers may eventually be able to purchase their own computers to access valuable information on aquaculture from the College website.

- Instructors: By reducing the need to travel, instructors will have more time for teaching and other duties. They will also gain computer and Internet research skills, and enhance their teaching and instructional design skills for DE courses.

- NetNam: NetNam will use this project to further its research to adopt Internet tools and resources for Vietnamese conditions.

- Fisheries College Number 4: By increasing its capacity to meet learner needs, reduce costs in the long term, and pioneer innovative teaching methods, the College will gain prestige and increase capacity to assist other colleges and universities in Vietnam to enhance their DE skills.

- Ministry of Fisheries: The Ministry will have access to innovative and necessary training to promote its goals of poverty reduction and increased employment for the Vietnamese people in the fisheries sector.

\section{Current and Future Developments}

In December 2002, the IDRC accepted the College's proposal and contracted with the College of the North Atlantic, Newfoundland, Canada, to begin implementing the plan. As of April 2003, progress was on schedule, and the College was purchasing computers for its main campus and the provincial extension centre. While aware of the risks inherent in the project, the IDRC believes that the willingness and enthusiasm of the College administration and staff for the project will be enormously helpful in the likely event of difficulties (Lafond, 2003). 


\section{Conclusions and Recommendations}

In conclusion, the first author found the College Number 4 project to be interesting and satisfying on professional and personal levels. As a part-time Athabasca University student enrolled in the Master of Distance Education program, the author was gratified to put theory into practice. It was professionally gratifying to know that her efforts would benefit others in fundamental ways, since a well-designed program could contribute to basic economic development in poor provinces. Experiencing the warm and gracious hospitality of her Vietnamese hosts, she found it enjoyable to work once again in a cross-cultural environment.

Looking back, the key lessons learned from the project included:

- Preparation Pays: Prior to leaving for Vietnam, the first author consulted with academics (at Athabasca and elsewhere) for advice on the academic culture in Vietnam, as well as the key aspects to be considered in establishing a DE program. Business people and other consultants with experience in the region provided tips on business etiquette, cultural mores, and related topics. Recent travelers to Vietnam provided hints on the mundane to the exotic: where to stay, what to pay, and where to eat. As a result of the generosity of these people, the first author encountered few cultural surprises and was able to concentrate her efforts on the task at hand.

- Translation Counts: At first language problems were a concern for the first author, since the College translator tired quickly and encountered difficulties when the conversation moved beyond pleasantries. When a more experienced translator became involved, the project proceeded much more smoothly. In future projects, it would be preferable to bring one's own translator to initial meetings, until it was clear that the "house" translator was up to the demanding work of translating technical jargon and information, often for hours at a time.

- More Time, The Better: In any project, it becomes a refrain: "If only we had more time.” The two weeks the first author was in Vietnam were jam-packed, with work every day from early in the morning until late at night. Still, it would have been preferable for her to have had more time to interview college staff regarding their views on the project, and to meet with some farmers who would be taking courses. The information and perspectives they would have provided would have no doubt been beneficial to the proposal development. It would have also been good for the author to have had an opportunity to become more knowledgeable of other DE projects that may have been underway in the country.

As the project moves along, the first author will keep abreast of its doings, since the IDRC has suggested a midterm and final evaluation of the project. This will be an excellent opportunity for the author to evaluate the effectiveness of the project design and ascertain, once again, how well theory works in real life.

\section{References}

Asian Association of Open Universities. (1990). Interactive communication in Distance Education. Jakarta, Indonesia: Universitas Terbuka.

Central Intelligence Agency. (2002). The World Factbook 2002 - Vietnam. Retrieved April 8, 2003, from: www.odci.gov/cia/publications/factbook/geos/vm.html 
Casas-Armengol, M., and Stojanovich, L. (1990). Some Problems of Knowledge in Societies of Low Development: Different perspectives on conceptions and utilization of advanced technologies in distance education. In M. Croft, I. Mugridge, J. S. Daniel, and A. Hershfield (Eds.) Distance Education: Development and access (p. 130-133). Caracas: International Council for Distance Education.

Chang, P. (2003). Personal communication. (February 26).

Chung, F. (1990). Strategies for developing distance education. In M. Croft, I. Mugridge, J. S. Daniel, and A. Hershfield (Eds.) Distance Education: Development and access. (p. 6166). Caracas: International Council for Distance Education.

Global Distance Learning Network (2001). A Country Report on Open and Distance Learning in Vietnam. Retrieved April 7, 2003, from: http://gdenet.idln.or.id/country/ar_vietnam/CRVietnam.htm

Global Distance Learning Network (2002). Facing global competition: Open learning and technology: problems and promises. Retrieved April 7, 2003, from: http://gdenet.idln.or.id/symposium/program.asp

Chang, P. (2003). Personal communication. (February 26).

McTavish, I. (2003). Personal communication. (Feburary 21).

Murray, S. (2003). Personal communication. (February 25).

Nelson, M. (2003). Personal communication. (February 19).

Nguyen, D. (2003). Personal communication. (February 18).

Nguyen, N. (2003). Personal communication. (February 18).

Penalever, L. M. (1990). Distance Education: A strategy for development. In M. Croft, I. Mugridge, J. S. Daniel, and A. Hershfield (Eds.) Distance Education: Development and access (p. 21-30). Caracas: International Council for Distance Education.

Son, T. T. (2001). Distance education and its contribution to rural development. Retrieved on April 7, 2003, from: http://www.undp.org.vn/mlist/cngd/032002/post11.htm

Wyne, D. (2003). Personal communication. (September 4).

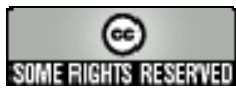

